\title{
Legal protection assessment of different inland wetlands in Chile
}

\author{
Patricia Möller ${ }^{1,2^{*}}$ and Andrés Muñoz-Pedreros ${ }^{3}$
}

\begin{abstract}
Background: Inland wetlands are well represented ecosystems in Chile that are subjected to various pressures affecting conservation. Protection means legal and administrative initiatives which promote the protection and/or preservation of a wetland, either in its entirety, considering their areas of influence or its components.

Results: The aim of this work is to develop a methodology for estimating the value of protection of different types of inland wetlands in Chile. For this purpose: a) the Chilean regulations in relation to the issues of biodiversity, wetlands and water resources were compiled; (b) such legislation and its application were analyzed, (c) protection and restriction values of each legal standard was estimated, and then total protection value of standards applied to six types of wetlands in study. 47 legal rules related to protection of inland wetlands and eight directly or indirectly affecting conservation and wise use of wetlands were identified.

Conclusions: In Chile there is no specific statutory rules or regulations on wetlands. Current legal standards do not protect equally the different types of inland wetlands, being swamp forests, peatlands and brackish Andean lakes less protected. To improve wetlands conservation, incentives promoting wetlands destruction must be eliminated and promulgate specific regulations for proper management and conservation.
\end{abstract}

Keywords: Inland wetlands; Legal standards; Real protection; Wetland protection

\section{Background}

Chile is highly diverse in limnic systems mostly recognized as wetlands and defined as 'areas of marsh, fen, peatland or water, whether natural or artificial, permanent or temporary, static or flowing, fresh, brackish or salt waters, including areas of marine water where tide depth does not exceed the six meters' (Ramsar 2000). This long definition includes very heterogeneous areas, such as swamps, rivers, lakes, seashores, and others (Mitsch and Gosselink 2000). Wetlands are highly productive ecosystems (Novitzki et al. 1996) characterized by multiple roles, e.g. hydrological, biogeochemical, habitat conservation, and food webs (Woodward and Wui 2001), as well as providing goods and services relevant to human society (Barbier et al. 1997). In Chile, wetlands are estimated to cover $4,498,060$, 7 ha equivalent to $5.9 \%$ of national territory (CONAF/CONAMA 1997).

\footnotetext{
* Correspondence: pmoller@ceachile.cl

${ }^{1}$ Facultad de Ciencias, Universidad Austral de Chile, Casilla 567, Valdivia, Chile ${ }^{2}$ Programa de Humedales, Centro de Estudios Agrarios y Ambientales, Casilla 164, Valdivia, Chile

Full list of author information is available at the end of the article
}

Wetlands support high biodiversity and are presently recognized as the most threatened systems by human activities (Marín et al. 2006). It affects various types of wetlands in Chile (Muñoz-Pedreros 2004, Peña-Cortés et al. 2006, Zegers et al. 2006, Figueroa et al. 2007). Particularly, freshwater aquatic fauna conservation is mostly affected, such as fishes (Vila et al. 2006), amphibians (Díaz-Paéz and Ortiz 2003, Veloso 2006), molluscs (Valdovinos et al. 2005), and decapod crustaceans (Bahamonde et al. 1998, Pérez-Losada et al. 2002). Inland wetland conservation is a global priority (Abell 2002, Dudley 2008). However, their particular territorial location and the difficulty to apply current protection categories make a difficult management as protected areas. As traditional ecosystem conservation methods are not well implemented in inland aquatic environments, different conceptual approaches are suggested (e.g. freshwater focal area, critical management zone, and catchment management zones (Abell et al. 2007)).

Governance concept applied to natural resources, mainly in waters, has become important (Iza and Rovere 2006). Governance is understood as the economic, political, and

\section{实 Springer}


administrative practice to manage every country affair. This includes mechanisms, processes, and institutions by which citizens express their interests, exercise their rights, meet their requirements, and mediate their differences. In this context, conservation of wetlands should be addressed under various environmental management tools as a permanent process, where various stakeholders and public, private, and civil society develop specific efforts to preserve, maintain, restore, and make a sustainable use of environment. Environmental management uses different and diverse origin instruments, which can be classified in four main categories (sensu Rodríguez-Becerra and Espinoza 2002): direct regulation, administration, economics, and education (including research, technical assistance, and environmental information). Direct regulatory tools which are also known as command and control regulations prevail in the environmental management and consist of mandatory regulations and standards, which establish environmental quality targets as well as management and preservation of renewable natural resources of environment. Legislation creates legal tools and standards to comply with principles and reach the aims (Asenjo 2006).

Brañes (2000) defines the environmental regulation as a set of standards dealing with legal protection of those conditions making every life to be possible, considering for this purpose relationships among many biotic and abiotic elements in the environment, such as system or ecosystem. To Fernández (2004), the environmental law gathers standards, regulations, and principles recognized as legally protected, safeguarding environmental systems, in a global and inclusive perspective that differ from merely legislation of environmental incidence.

It may be understood here that legal protection of wetlands is provided by all legal and administrative initiatives aimed to protect and/or preserve them. There are many legal standards that apply to inland wetlands in Chile, many of them are sectoral standards related to their components, ecological functions, and biodiversity, which would favor or regulate their status and permanence. Selection and analysis of these regulations will allow to provide foundations, which make possible assessment of legal degree protection that they provide to these systems and to integrity as ecological systems. In Chile, regulations addressed to the conservation of water resources as a whole have been mainly aimed to develop economic activities related to the exploitation of a natural resource. Until 1994, prior to the Environmental Basis Act (Act No. 19,300) enactment, there were only sector legal standards, without global environmental protection objective, where legal rules were mainly aimed to protect health of human life and only incidental protection of nature (Olivares 2010). Act No. 19,300 started regulation process of environmental standards, as well as the creation of institutions providing the state of management tools in this area (Rojas 2011).
However, Hermosilla (2004) estimates that while keeping current protection system and guarantees of property rights in Chile over the common well, effective protection to natural systems including wetland ecosystems will not be possible.

Prior this research, there was no compilation and analysis of rules applied to wetland systems which allows to determine real legal protection in taking care of conservation, but there are legal standards which should be assessed under this context, like those regulations enacted which damage preservation and rational use of inland wetlands. The rational use concept is defined by the Ramsar Convention as the maintenance of ecological features, achieved through the implementation of ecosystem-based approach, within sustainable development context.

Under the Chilean legal system, environmental heritage conservation is the rational use and exploitation or repair if any, of environment components, to assure sustainability and regeneration capacity (Act No. 19,300; Article 2b); however, it does not point out which are those components.

Some environmental components, those considered to be relevant issues for this study among them, are noted by Fernández (2004): a) land or sea waters, surface water or groundwater, streams or standing waters; b) land, soil and subsoil, including beds, bottom and subsoil of ground waters; c) flora and wildlife, land or water; d) microflora and fauna of land, soil and subsoil, streams or water bodies and beds, bottoms and subsoil of these streams or water bodies; e) genetic diversity and patterns and factors regulating flow; f) natural scenic beauty and rural or urban landscape; g) essential ecological processes. These basic components of the environment can be damaged when misused which results in extinction or serious damage, prevents regeneration, and causes environmental damage determined in law as 'any loss, decrease, impairment, or significant impairment associated to environment or to one or more of its components' (Act No. 19,300: Art. 2e).

Some of the elements or factors which could damage or degrade the environment are (to Fernández 2004): a) any kind of pollution; b) erosion, salinization, alkalinization, infestation, flooding, sedimentation, and desertification of soil and land; c) logging or unreasonable and uncontrolled destruction of trees and shrubs as well as extractive forest use and other vegetation destruction; d) monocultures, overgrazing, and, as a whole, any cultural practice with harmful effects on the environment; e) sedimentation of water streams and lakes; f) harmful alterations of natural water flows; g) adverse changes and misuse of water beds; h) wild flora and fauna over-exploitation; i) elimination, destruction, or degradation of endangered species from flora and fauna habitat; j) wetland eutrophication origins; k) introduction or distribution of exotic plants or animals 
coming from a national biogeographical province different to natural; l) introduction or spread of animal diseases or plant pests; $m$ ) use of non-biodegradable products or substances; $n$ ) the accumulation of waste or inappropriate waste disposal; o) visual landscape destruction or alteration, and, as a whole, any act or omission affecting negatively the basic composition, behavior, and natural potential of environment; threatening land genetic viability or affecting life, health, integrity, or development of man, plants, or animals. These environmental components and environmental degradation factors were considered in the analysis of rules to determine protection concept granted by the Chilean law to the rational use of wetlands. Thus, the aim of this work is to develop a multicriteria methodology to quantify the level of legal protection that different types of inland wetlands have in Chile.

\section{Methods}

\section{Compilation and analysis of current standards}

Compilation and analysis of current legislation related to wetlands and water resources, including legal standards with description and characterization, was carried out, consulting different sources of reference (e.g., CONAMA 1996a, 1996b, 1997a, 1997b, 2009, Castillo 1994, Gallardo 1985 Hermosilla 2004, Ortiz 1986, 1990, Valenzuela 1994,
Fernández 2004, Bravo 2010). Also, the website of the Library of Congress of Chile was reviewed (www.leychile.cl), which has a compendium of environmental legal standards and acts classified by topics. The review covered Chilean regulations until April 2012.

The identification of the corresponding legal standards was based on the interest of this study (e.g., fresh water fauna, water resources, wetlands, watersheds), selecting standards aimed at protecting and preserving aspects and components involved in direct or indirect conservation of inland wetlands. Legal standards in force which restrict conservation and protection of inland wetlands, as well as issues related to functionality and biodiversity, were also identified. Selected rules were hierarchically ordered according to Gallardo (1985).

\section{Multicriteria method for legal protection assessment}

Wetland legal protection will tend to protect and/or conserve, either entirely, in components or considering the influence areas. This protection was estimated with a multicriteria methodology developed according to the following procedure (Figure 1): (a) compilation and analysis of existing legislation related to inland wetland issues (aspects related to biodiversity conservation and rational use included); also, current regulations which restrict conservation and rational use of inland wetlands

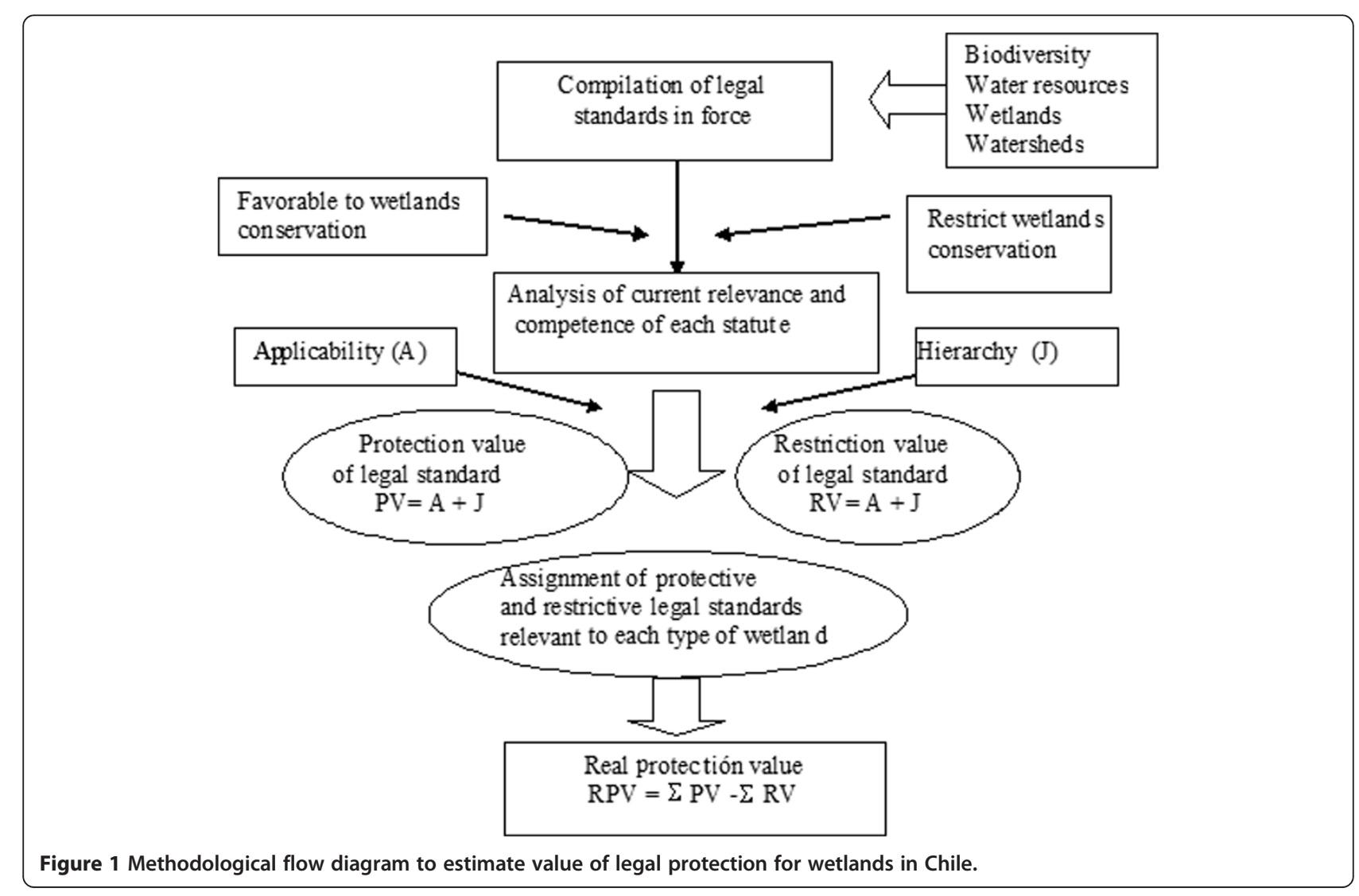


were identified; (b) estimation of protection value (PV) provided by each legal regulation that considers applicability and standard hierarchy; (c) estimation of restriction value (RV) provided by each legal regulation instrument that also considers applicability and legal standard hierarchy; and (d) finally, estimation of real protection value (RPV) by summing protection values (PVs) of each legal standard applied to wetland of interest and restriction values (RVs) applied to the same type of wetland.

\section{Protection value (PV) calculation}

Protection value considers applicability and legal standard hierarchy (Figure 1). Applicability (A) is given as expressly enacted for wetland conservation purposes (value 3 ); or if secondarily, it could be considered as it refers to conservation of some environmental components emphasizing the aquatic system as a natural system (value 2), or if it is only tangential or generically involved with conservation of any component without reference to the natural system (value 1). Legal standards applicability was assessed, considering the reference which protects or preserves. It was classified in three levels: a) wetland system, including reference to 'wetlands' 'aquatic environment', 'aquatic ecosystems', or 'biodiversity' concepts (in ecosystem level); b) components, e.g., water, flora, and plants, with reference to aquatic system (e.g., river or lake); and c) component, e.g., water, wildlife, flora, or vegetation, without reference to aquatic system. These three levels were assigned with values 3,2 , and 1 respectively, getting applicability of each of the legal regulations. Hierarchy $(\mathrm{H})$ was assessed by assigning the maximum value (3) to legal regulations, an average hierarchy (value 2) to decrees with force of law and law decrees, and lower hierarchy (value 1) to standard rules (e.g., regulations, simple decrees, instructions, supreme decrees, resolutions). For details of this hierarchy, see Additional file 1.

Legal protection estimated value (PV) was calculated using the following formula: $\mathrm{PV}=\mathrm{A}+\mathrm{J}$, where $\mathrm{PV}=$ legal protection value of each legal rule, $\mathrm{A}=$ applicability of standard to each wetland type, and J = hierarchy that the standard has in the law of Chilean legal system. Thus, the protection value (PV) of each legal instrument is deployed between $2(\mathrm{PV}=1+1)$ (minimum protection) and $6(\mathrm{PV}=$ $3+3)$ (maximum protection). The sum of the variables considers that the weight of each is the same.

\section{Restriction value (RV) calculation}

It is estimated by analyzing protection restrictions of legal standards and the rational use of diverse wetlands. Applicability and legal hierarchy standards (Figure 1) were also considered. Applicability (A) was determined, considering what and how does it affect wetlands. The implementation effects are the complete wetland system destruction or any structural component (value 3); collateral effect (value 2) and whether it may only eventually affect (value 1 ). Hierarchy $(\mathrm{H})$ was valued in same way as the protection value. Restriction value (RV) was calculated as: $\mathrm{RV}=\mathrm{A}+\mathrm{J}$, where $\mathrm{RV}=$ restriction value of each legal rule, $\mathrm{A}=$ statute applicability, and $\mathrm{J}=$ standard hierarchy. Thus, restriction value (RV) to each legal regulation is deployed between $2(\mathrm{VR}=1+1)$ (minimum constraint) and $6(\mathrm{RV}=3+3)$ (maximum constraint). The sum of variables considers the weight of each one to be the same. Integration of parameters included and their subsequent validation was done by a team of 11 experts using the method of Delphi (Linston and Turoff 1975). The group of experts included professionals from different disciplines, with over five years of professional experience, who in spite of not having legal formation, they were linked to these subjects. Criteria considered specialists in aquatic resources (4), relation with public institutions (3), and environmental management experience (5) (see shaping panel at Additional file 1). Work methodologies were workshops, documents, and questionnaire previously associated, which were duly submitted to experts to review and compile observations by using templates. Observations from experts were systematized and incorporated to a document which was forwarded for assent repeating procedure described to obtain consensus. The algorithm was applied to different types of inland wetlands of Chile.

\section{Wetlands studied}

Six types of wetlands were selected based on representativeness and wetland they represented. Representation considered frequency, defined as abundance, in a survey of 1,215 inland wetlands (CEA/FIP 2010), with Scott and Carbonell records (1986); Schlatter et al. (2001); and Lopez-Lanus and White (2005), which was refined and grouped according to the type by Dugan (1992) and considerations by Ramsar (2000) and Ramirez et al. (2002). Based on the above, selected wetlands correspond to fluvial systems, lakes, and palustrine areas, which are: (a) rivers, (b) lagoons, (c) brackish Andean lakes, (d) highaltitude Andean peatlands called 'vegas' and 'bofedales', (e) freshwater swamp forests, and (f) permanent freshwater marshes and swamps also called locally as 'bañados' and 'ciénagas'.

\section{Results}

\section{Legal standards for wetland protection}

Standards were selected either since they address wetland as entirety natural system or they refer to some constituting component, such as water (in quality), aquatic life, wildlife, and others, as well as the environmental and aesthetic roles. Same way, those referred to any basin component with impact on aspects above 
mentioned (conservation of watershed vegetation, woodland springs, and riparian zones) were also included. Those standards which currently or potentially damage wetlands or any of their components were also included. Rules were considered from current or potential application point of view. Forty-seven legal rules directly or indirectly related to the protection of wetlands were identified (for each rule purpose, see Additional file 1).

\section{Protection value (PV) of legal standards}

Each legal standard protection value is shown in Table 1, which presents 47 legal rules with each potential protection value, according to applicability and hierarchy. It can be observed that they mostly (30 standards) have protection values 2 or 3 , it means low; and 11 standards have intermediate protection value (value 4 ) while only six standards have higher protection values (values 5 and 6). The total protection value given by adding all protection standards is 144 .

Table 2 presents legal protection value provided by legal standards to different types of inland wetlands in Chile. Zero values indicate that standard does not apply. From 47 standards identified, 46 of them apply to rivers, providing total protection value of $141 ; 27$ apply to brackish Andean lakes, providing total protection value of 80; 44 apply to lagoons, providing total protection of 134; 28 apply to peatlands ('vegas' and 'bofedales') with total protection of $83 ; 32$ apply to swamp forests, providing total protection of 98 ; and 34 apply to marshes ('bañados' and 'ciénagas'), giving full protection of 102. As shown in Table 2, greater legal protection is provided in descending order: to rivers, lagoons, marshes, swamp forests, and finally, peatlands and brackish Andean lakes have the lowest legal protection values.

\section{Restriction value (RV) of legal standards}

Eight legal restriction standards considered affecting conservation, and rational use of wetlands (Table 3) was identified. Some of these standards are also included in the protection regulations since their articles incorporate both protection and restriction issues for wetland conservation. Legal restriction applicability was assessed considering what and how it affects the wetland system. In this case, unlike the rules of protection, three applicability levels were not identified, since every effect caused by standards are supposed to affect the entire system or biological diversity, which was also considered at ecosystem level, so all were assigned with value 3 . Table 3 also shows restriction value to conservation or sustainable use that provides laws to wetlands, and Table 4 shows their application to different wetland types considered in this study. Zero values indicate that standard does not apply.
Restriction to sustainable use of wetlands established by legal standards to different types of inland wetlands reveals that the eight identified standards provide a total restriction value of 42 . Wetlands mostly affected are rivers and swamp forests, both with five standards, and restriction values of 28 and 25, respectively, followed by lagoons with three rules and restriction value of 18 and marshes with two rules and a restriction value of 12 . Least affected are brackish Andean lakes and peatlands to which a single standard applies, giving restriction value 6

\section{Real protection value (RPV)}

Real protection value (RPV) was estimated once the number of legal rules applied to each type of wetland is established (Figure 1). This value is obtained by summing protection values (PVs), given by all legal standards applied to each type of wetland; and subtracting restriction values (RV), given by all legal standards that apply to the same wetland, as follows: RPV $=\Sigma P V-\Sigma R V$. Distribution of values is grouped into three ranges, giving following nominal values: value 1 to less protected wetlands, value 2 to intermediate protected ones, and value 3 to the best legally protected wetlands. The real protection value (RPV) given by the set of laws applied to different types of wetlands in the study is presented in Table 5. This (RPV) is deployed between 73 and 116 . These values were grouped into ranges to where numeric values between 1 and 3 (Table 6) were assigned, being 3 the highest protection value and 1 the lowest protection value.

Real protection provided by laws is higher (value 3 ) in rivers and lagoons, intermediate (value 2) in marshes, and low (value 1) in brackish Andean lakes, peatlands, and swamp forest. So, the best protected wetlands, according to the number and legal hierarchy affecting direct or indirect protection, are rivers and lagoons. Wetlands with intermediate protection category are marshes and peatlands. Finally, the least protected are brackish Andean lakes, peatlands, and swamp forests.

\section{Discussion}

General review of legal standards affecting conservation of wetlands in Chile reveals that before year 2012, there were no laws addressed to wetlands as ecosystem, since they only involved some components (water, flora, wildlife). The first reference to wetland concept in the Chilean law, except acts related to Ramsar Convention adhesion enacted in 1981, appears in 1994 with Act No. 19,300, one time mentioned.

Same way, wetland definition arises for the first time in 2011 by act of Supreme Decree $N^{\circ}$ 82, Soil, water, and Wetlands Regulations Act No. 20,283. This is the 
Table 1 Applicability (A) of legal standards affecting Chile's inland wetlands depending on what it protects or preserves, hierarchy $(\mathrm{J})$ and protection value (PV) of each legal rule, as well as it total value protection

\begin{tabular}{l} 
Legal standard \\
\hline Act N¹9,300 \\
DS N ${ }^{\circ} 531$ Washington Convention \\
DS No141 CITES \\
DL N ${ }^{\circ} 3,485$ Ramsar Convention \\
DS N ${ }^{\circ} 868$ Migration of species \\
Decree No 1,963 Convention in biodiversity \\
Act No 11,402 Barrier works and standardization of bank and channel \\
Act No 17,288 National Monuments \\
Act No 18,892 Fishery and Agricultural Standards
\end{tabular}

Act $N^{\circ} 18,902$ Sanitary health superintendency creation; liquid industrial residues control

Act $N^{\circ} 19,473$ Hunting Law

DFL N 208 Provisions for development of fishing activities

DFL N 701 About forest development

Act N 20.283 Native Forest Recovery and Forestry Development rule

Act $N^{\circ}$ 20,256 Recreational fishing standards

Act $N^{\circ}$ 20,411 Prevents constitution of water rights

DFL N ${ }^{\circ} 725$ Sanitary Health Legal StandardsArt. 73

DFL N 1,122 Water Legal Standards

DS $N^{\circ} 1$ Regulations for water pollution control

DS N 5 Hunting law approval

DS N 29 Approval of classification standards according to wild species conservation conditions

DS N ${ }^{\circ} 30$ Law 19,300

DS N 46 Groundwater emission standards

DS N $N^{\circ} 3$ Classification process of species according to conservation condition

DS N ${ }^{\circ} 41$ Classification process of species according to conservation condition

DS N 42 Classification process of species according to conservation condition

DS N $N^{\circ} 51$ Classification process of species according to conservation condition

DS N ${ }^{\circ} 82$ Soil, water, and wetlands legal standardsAct $N^{\circ} 20,283$

DS N ${ }^{\circ} 90$ Standards for liquid residues discharge into surface freshwater

DS No 95 Environmental Quality Standards Law

DS Nº 93 (2009) Native Forest Recovery Law

DS N 193 Law Decree 701 General rules

DS N 210 Reforestation and recreational fishing standards

DS N 236 Standards for disposals not discharged to sewage network

DS N 238 Park and marine reserves standards (including inland waters)

DS N ${ }^{\circ} 320$ Aquaculture environmental standards

\begin{tabular}{cccc} 
What protects/preserves? & A & J & PV \\
\hline Environment & 3 & 3 & 6 \\
Flora and fauna in protected area systems & 1 & 1 & 2 \\
Components (flora and fauna) & 1 & 1 & 2 \\
Systems (wetland) & 3 & 2 & 5 \\
Component (fauna) & 1 & 1 & 2 \\
Biological diversity & 3 & 1 & 4 \\
Reforestation river basin (headwaters) & 2 & 3 & 5 \\
Sites (Research interests) & 1 & 3 & 4 \\
Components (fauna, such as hydro-biological resources (fisheries & 2 & 3 & 5 \\
and aquaculture)) & & & \\
Component (water quality for human purposes) & 1 & 3 & 4 \\
Components (fauna) & 1 & 3 & 4 \\
Components (water quality, fish, and seafood) & 1 & 2 & 3 \\
Components (soil for quality purposes/water quantity for & 1 & 2 & 3
\end{tabular}

Components (native forest associated to springs, natural bodies, 336 and water courses)

Ecosystem

$\begin{array}{lll}3 & 3 & 6\end{array}$

Components (aquifer)

$\begin{array}{lll}1 & 3 & 4\end{array}$

Components (quality/water quantity and human health)

123

Components (water supply quantity for human use)

$\begin{array}{lll}2 & 2 & 4\end{array}$

Components (water supply quantity for human use)

Components (fauna)

$\begin{array}{lll}1 & 1 & 2\end{array}$

$\begin{array}{lll}1 & 1 & 2\end{array}$

Components (wild species)

112

Systems (wetland)

$\begin{array}{lll}3 & 1 & 4\end{array}$

Components (water supply quantity for human use)

$\begin{array}{lll}1 & 1 & 2\end{array}$

Components (wild species)

112

Components (wild species)

112

Components (wild species)

112

Components (ichthyofauna species)

112

Systems (bodies and natural waterflows)

$\begin{array}{lll}3 & 1 & 4\end{array}$

Components (water quality in four types of use)

112

Components (water quality for human and environmental $\quad 2 \quad 1 \quad 3$ health)

Components (native forest with soil, water, and wetland $\quad \begin{array}{lll}3 & 1 & 4\end{array}$ protection areas)

Components (soil, courses and water bodies, flora and fauna) $\quad 1 \quad 1 \quad 2$

Components (ichthyofauna) 112

Components (water quality for human consumption) $\quad \begin{array}{llll}1 & 1 & 2\end{array}$

$\begin{array}{llll}\text { Systems (wetland) } & 3 & 1 & 4\end{array}$

Systems (river and lake) $\quad 2 \quad 13$ 
Table 1 Applicability (A) of legal standards affecting Chile's inland wetlands depending on what it protects or preserves, hierarchy $(\mathrm{J})$ and protection value (PV) of each legal rule, as well as it total value protection (Continued)

DS N 430 Reviewed document for fisheries and aquaculture Law

Systems (river and lake) 213

DS N 594 Health and work place environmental condition standards

DS N 351 Industrial liquid residues discharge depuration and neutralization standards

DS N 609 Standards for industrial liquid residues to sewerage

DS $N^{\circ} 4,363$ Forest law approval

DS N $N^{\circ}$ 2,374 Standards for forest exploitation in forest watersheds and dams

Decree $N^{\circ} 878$ Prohibition to extractive native fish in inland waters

NCh $N^{\circ} 1,333 / 87$ Chilean standard for water quality

Secondary standards for environmental quality

Resolution N 425 Groundwater exploration and exploitation standards Resolution N 197 Loa River reduction to new exploitation feeding

Total protection value

DS Supreme Decree, DL Law Decree, DFL Decree with Force of Law, NCh Chilean Standard, CITES Convention on International Trade in Endangered Species of Wild Fauna and Flora.

evidence of the lack of consideration and the late inclusion of these ecosystems in the country regulations.

There is a different legal protection to different types of inland wetlands since current legislation in Chile does not provide equal protection to the different types of wetlands. Lagoons and rivers have the highest legal protection values due to the large number of regulations applied favorably to these systems and fewer standards that affect them adversely. For marshes, the intermediate value of legal protection comes from that; in spite, there are a number of regulations favoring conservation, and there are a few restrictions affecting them.

Andean systems (brackish lakes and peatlands) present different condition; since in spite a few restriction standards affecting them, they are poorly protected by current legislation. Swamp forest is the most dramatic case; which in spite of important existing regulatory standards that should protect them, they are the most affected ones by the restriction rules. The greatest impacts are Act No. 18,450 which promotes irrigation and drainage and Decree Law No. 701 about forest development. These regulations subsidize up to $75 \%$ of activities which enable the poorly drainaged lands to become agricultural territory, which means the main threat to swamp forests of coastal watersheds in La Araucanía region (Urrutia 2005, García 2005) and its evolution towards greater fragmentation in recent years (Peña-Cortés et al. 2011).

Legal standards above mentioned are clear perverse incentives and disincentives to the rational use of wetlands in Chile.

One aspect considered relevant in the Ramsar Convention was to assess effectiveness of legislative and institutional measures related to promote the conservation and the rational use of wetlands, are sectoral legal and institutional measures affecting wetlands such as financial and tax incentives to convert them. Nelson (1986) noted that wetland policies in the US and UK had administrative divisions with antagonistic competences. So, while the US Department of Agriculture provided incentives to drainage, the Interior Department was promoting conservation of wetlands, same way that the Ministry of Agriculture, Forestry, and Fisheries and the Nature Preservation Council faced each other in the UK. This problem was addressed in the US by removing some incentives for wetland drainage, which also included other conservation and education measures (Dahl 2000), reducing by $80 \%$ the wetland loss tendency between 1986 and 1997 compared to previous decade. Apparently, some Latin American countries have also advanced on this subject. For example in Ecuador, the legislation review by Echeverría (2008) about wetland management does not identify measures that indirectly support the loss or degradation of wetlands through negative incentives.

Review of some national reports presented by countries as contracting party in the last conference of the Ramsar Convention, held in Bucharest, Romania in $2012^{a}$ (COP11), allowed to know measures that countries reported as implemented regarding incentives which promote the conservation and the rational use of wetlands, as well as those intended to remove perverse incentives which discourage them.

USA is the American country with the highest amount of initiatives on this subject. Report to $\mathrm{COP} 11^{\mathrm{b}}$ indicates several provisions that discourage conversion of wetlands to cropland. The federal Swampbuster policy, provision of Food Security Law dated 1985, has eliminated the policy incentives and other mechanisms which have technically 
Table 2 Protection value and number of legal standards to different types of inland wetlands in Chile Legal standards/protection value

$\begin{array}{ccc}\begin{array}{c}\text { VP potencial Rivers } \\ \text { wetlands }\end{array} & \begin{array}{c}\text { Brackish Lagoons } \\ \text { Andean } \\ \text { lakes }\end{array} & \begin{array}{c}\text { High-altitude } \\ \text { Andean } \\ \text { peatlands }\end{array}\end{array}$

shwater

akes peatlands

swamp

forests freshwater marshes and swamps

Act $N^{\circ} 19,300$

DS N 531 Washington Convention

DS N 141 CITES

DL N³,485 Ramsar Convention

DS Nº 868 Migratory species (Bonn Convention)

Decree $N^{\circ} 1,963$ Convention on Biodiversity

Act $N^{\circ} 11,402$ Barriers and river banks and streams

Act $N^{\circ} 17,288$ National Monuments

Act $N^{\circ} 18,892$ Aquaculture and Fishing Law

Act $N^{\circ} 18,902$ Sanitary health superintendency creation; industrial liquid residues control

Act $N^{\circ} 19,473$ Hunting Law

DFL N 208 Provisions to fishing development

DFL N 701 About forest development

Act $N^{\circ} 20,283$ Native Forest and Forest Development Recovering Law

Act $N^{\circ}$ 20,256 Recreative fishing standards

Act $N^{\circ}$ 20,411 Prevent constitution water rights

(Arica/Parinacota a O'Higgins)

DFL N 725 Sanitary CodeArt. 73

DFL N 1,122 Water Code

DS $N^{\circ} 1$ Aquatic pollution control rules

DS $N^{\circ} 5$ Hunting law standard approval

DS N $N^{\circ} 29$ Approval of classification of species standards based on conservation conditions

DS N 30 Act 19,300 Standards

DS N ${ }^{\circ} 46$ Groundwater discharge standards

DS N 33 Classification process of species according to conservation condition

DS $N^{\circ} 41$ Classification process of species according to conservation condition

DS N 42 Classification process of species according to conservation condition

DS N 51 Classification process of species according to conservation condition

DS Nº 82 Act No. 20,283 Soil, water, and wetland regulations

DS $N^{\circ} 90$ Standards to liquid residue discharge into surface fresh water

DS N 93 (1995) Primary and secondary environmental quality standards

DS N 93 (2009) Native Forest Recovery and Forestry Development rules

DS N 193 DL N 701 General rules

DS N $N^{\circ} 210$ Regulation of reforestation and planting for recreational fishing

\begin{tabular}{|c|c|c|c|c|c|c|}
\hline 6 & 6 & 6 & 6 & 6 & 6 & 6 \\
\hline 2 & 2 & 2 & 2 & 2 & 2 & 2 \\
\hline 2 & 2 & 2 & 2 & 2 & 2 & 2 \\
\hline 5 & 5 & 5 & 5 & 5 & 5 & 5 \\
\hline 2 & 2 & 2 & 2 & 2 & 0 & 2 \\
\hline 4 & 4 & 4 & 4 & 4 & 4 & 4 \\
\hline 5 & 5 & 0 & 0 & 0 & 0 & 0 \\
\hline 4 & 4 & 4 & 4 & 4 & 4 & 4 \\
\hline 5 & 5 & 0 & 5 & 0 & 0 & 0 \\
\hline 4 & 4 & 4 & 4 & 4 & 4 & 4 \\
\hline 4 & 4 & 4 & 4 & 4 & 4 & 4 \\
\hline 3 & 3 & 0 & 3 & 0 & 0 & 0 \\
\hline 3 & 3 & 0 & 3 & 0 & 3 & 3 \\
\hline 6 & 6 & 0 & 6 & 0 & 6 & 6 \\
\hline 6 & 6 & 0 & 6 & 0 & 0 & 0 \\
\hline 4 & 4 & 4 & 4 & 4 & 4 & 4 \\
\hline 3 & 3 & 0 & 3 & 0 & 0 & 0 \\
\hline 4 & 4 & 4 & 4 & 4 & 4 & 4 \\
\hline 2 & 2 & 2 & 2 & 0 & 0 & 0 \\
\hline 2 & 2 & 2 & 2 & 2 & 2 & 2 \\
\hline 2 & 2 & 2 & 2 & 2 & 2 & 2 \\
\hline 4 & 4 & 4 & 4 & 4 & 4 & 4 \\
\hline 2 & 2 & 2 & 2 & 2 & 2 & 2 \\
\hline 2 & 2 & 0 & 0 & 0 & 0 & 0 \\
\hline 2 & 2 & 0 & 2 & 2 & 2 & 2 \\
\hline 2 & 2 & 0 & 2 & 0 & 2 & 2 \\
\hline 2 & 2 & 2 & 2 & 2 & 0 & 2 \\
\hline 4 & 4 & 4 & 4 & 4 & 4 & 4 \\
\hline 2 & 2 & 2 & 2 & 0 & 0 & 0 \\
\hline 3 & 3 & 3 & 3 & 3 & 3 & 3 \\
\hline 4 & 4 & 0 & 4 & 0 & 4 & 4 \\
\hline 2 & 2 & 0 & 2 & 0 & 2 & 2 \\
\hline 2 & 2 & 0 & 2 & 0 & 0 & 0 \\
\hline
\end{tabular}


Table 2 Protection value and number of legal standards to different types of inland wetlands in Chile (Continued)

\begin{tabular}{|c|c|c|c|c|c|c|c|}
\hline $\begin{array}{l}\text { DS N }{ }^{\circ} 236 \text { Regulation not discharged sewage disposal to } \\
\text { sewer networks }\end{array}$ & 2 & 2 & 2 & 2 & 2 & 2 & 2 \\
\hline $\begin{array}{l}\text { DS N } N^{\circ} 238 \text { Regulation for parks and marine reserves } \\
\text { (including inland waters) }\end{array}$ & 2 & 2 & 2 & 2 & 2 & 2 & 2 \\
\hline DS Nº 320 Environmental aquaculture rules & 2 & 2 & 0 & 2 & 0 & 0 & 0 \\
\hline $\begin{array}{l}\text { DS N }{ }^{\circ} 430 \text { Consolidated, coordinated, and systematized } \\
\text { document on fishery law }\end{array}$ & 3 & 3 & 0 & 3 & 0 & 0 & 0 \\
\hline $\begin{array}{l}\text { DS N } N^{\circ} 594 \text { Rules for health and environmental conditions } \\
\text { in work places }\end{array}$ & 2 & 2 & 2 & 2 & 2 & 2 & 2 \\
\hline $\begin{array}{l}\text { DS N }{ }^{\circ} 351 \text { Rules for neutralization and depuration of liquid } \\
\text { industrial residues }\end{array}$ & 2 & 2 & 2 & 2 & 2 & 2 & 2 \\
\hline $\begin{array}{l}\text { DS N }{ }^{\circ} 609 \text { Standard for sewerage industrial liquid residues } \\
\text { discharge }\end{array}$ & 2 & 2 & 0 & 2 & 2 & 2 & 2 \\
\hline $\begin{array}{l}\text { DS N } N^{\circ} 2,374 \text { Regulation to forest exploitation in forest } \\
\text { watersheds and dams }\end{array}$ & 2 & 2 & 0 & 2 & 0 & 2 & 2 \\
\hline $\begin{array}{l}\text { Decree } N^{\circ} 878 \text { Native fish extraction prohibition in inland } \\
\text { waters }\end{array}$ & 2 & 2 & 2 & 2 & 2 & 2 & 2 \\
\hline NCh N 1,333/87 Chilean water quality standards & 3 & 3 & 0 & 3 & 3 & 3 & 3 \\
\hline Secondary environmental quality standards & 4 & 4 & 0 & 4 & 0 & 0 & 0 \\
\hline $\begin{array}{l}\text { Resolution N }{ }^{\circ} 425 \text { Establish groundwater exploration and } \\
\text { exploitation standards }\end{array}$ & 3 & 3 & 3 & 3 & 3 & 3 & 3 \\
\hline $\begin{array}{l}\text { Resolution N N } 197 \text { Declares Loa River reduction and } \\
\text { feeders for new farms }\end{array}$ & 3 & 0 & 3 & 0 & 3 & 0 & 0 \\
\hline Total standards & 47 & 46 & 27 & 44 & 28 & 32 & 34 \\
\hline Total legal protection value & 144 & 141 & 80 & 134 & 83 & 98 & 102 \\
\hline
\end{tabular}

DS Supreme Decree, DL Law Decree, DFL Decree with Force of Law, NCh Chilean Standard, CITES Convention on International Trade in Endangered Species of Wild Fauna and Flora.

and economically allowed the destruction of wetlands, acting and separating those who make it from other agricultural policy benefits. Federal efforts to restore wetlands have increased from 1987, with legal standards of critical preservation and restoration with two programs which stopped and even reversed loss as Wetland Conservation (WC) provisions of Agricultural Law in 1985 and the Wetlands Reserve Program (WRP) of Agricultural Law in 1990 (Coperland 2010).

In national report, $\operatorname{Canada}^{\mathrm{c}}$ indicates that measures to eliminate perverse incentives in some provinces consist of wetlands filling prevention rules which enable marginal agricultural soils and balance benefits provided by wetland drain restoration projects with cleaning, storage, and discharge of water functions fulfilled by wetlands. The $\mathrm{UK}^{\mathrm{d}}$ works reforms to agricultural policy to have a positive impact on marsh wetlands used for grazing by agri-environment patterns, management agreements, and other keeping administration systems.

The China ${ }^{\mathrm{e}}$ report indicates that diverse level governments and their departments have a strict control over every kind of activity that damages wetlands by enacting 11 provincial (autonomous regions) wetland conservation regulations, which prohibit several activities and perverse incentives. People convocation has taken the surveillance and control in the implementation of those laws at various levels. Australia ${ }^{\mathrm{f}}$ has already indicated in the COP10 national report 2008 about the National Water Initiative, Water for Future, and Water Law 2007 developed to stop perverse incentives in the water management. Same way, New Zealand ${ }^{g}$ declared in national report that they have eliminated subsidies to land development.

In South American countries ${ }^{\mathrm{h}}$, Bolivia, Colombia, Peru, and Chile state, they did not take measures to promote incentives to encourage conservation and rational use of wetlands. Countries showing incentives are Costa Rica by promoting private refuges, territory tax payment exemption, and payment for environmental services; Ecuador by applying tax exemption to rural land containing wetlands and monetary incentives to private owners and community which preserve Andean wetlands; and Argentina and Venezuela by providing financial incentives for conservation and planning in land management.

Regarding measures to remove perverse incentives, Bolivia, Brazil, Costa Rica, and Peru declare that they have not taken them. Ecuador and Venezuela note that they count with these measures. Uruguay, Colombia, and Chile indicate that these measures are being planned 
Table 3 Legal restriction standards which affects the rational use of inland wetlands in Chile, applicability (A) in terms of how and what affect to wetlands, hierarchy $(J)$ and restriction value (RV) of each legal standard and total restriction value

\begin{tabular}{|c|c|c|c|c|c|c|}
\hline Legal standard & Standard objective & How affect & What affect & A & J & RV \\
\hline Act $N^{\circ} 18,248$ Mining Law & $\begin{array}{l}\text { Property acquisition of a mining concession enables to request the mining right's } \\
\text { constitution and water right ownership. Written permission by governor is required } \\
\text { for mining operations at lower distance than } 50 \text { yards in flood barriers, waterways, } \\
\text { and lakes for public use. }\end{array}$ & $\begin{array}{l}\text { Intervention to wetland systems, } \\
\text { which may completely affect structure }\end{array}$ & $\begin{array}{l}\text { Every type of wetlands } \\
\text { (rivers) and lakes }\end{array}$ & 3 & 3 & $\frac{6}{6}$ \\
\hline $\begin{array}{l}\text { Act } N^{\circ} 20,256 \text { Standards for } \\
\text { recreational fishing }\end{array}$ & $\begin{array}{c}\text { Development of recreational fishing activity, and the economic and associated } \\
\text { tourist activities. }\end{array}$ & $\begin{array}{l}\text { Introduction of alien species affects } \\
\text { biodiversity and system as a whole }\end{array}$ & Rivers and lakes & 3 & 3 & 6 \\
\hline \multirow[t]{2}{*}{$\begin{array}{l}\text { Act } \mathrm{N}^{\circ} 11,402 \text { Barriers and } \\
\text { standardization of banks } \\
\text { and river flows }\end{array}$} & $\begin{array}{l}\text { Barrier works as well as standardization of banks and beds of rivers, lagoons and } \\
\text { tidelands carried out with legal involvement can only be executed and planned by } \\
\text { sanitary authorities of Public Works Ministry. }\end{array}$ & \multirow[t]{2}{*}{$\begin{array}{l}\text { Regularization of channels and gravel mining } \\
\text { extraction affecting the aquatic system } \\
\text { structure }\end{array}$} & \multirow[t]{2}{*}{$\begin{array}{l}\text { Rivers, lakes, and } \\
\text { streams }\end{array}$} & \multirow[t]{2}{*}{3} & \multirow[t]{2}{*}{3} & \multirow[t]{2}{*}{6} \\
\hline & $\begin{array}{l}\text { Extraction of gravel and sand from beds of rivers and streams should be carried out } \\
\text { with municipality permits, which may charge duties or subsidies. }\end{array}$ & & & & & \\
\hline $\begin{array}{l}\text { Act } N^{\circ} 18,450 \text { Rules for } \\
\text { private irrigation and } \\
\text { drainage development }\end{array}$ & $\begin{array}{l}\text { Cost analysis benefits, construction, and rehabilitation of irrigation as well as } \\
\text { drainage works to enable agricultural soils with poor drainage. }\end{array}$ & $\begin{array}{c}\text { Drainage of wetlands results in complete } \\
\text { destruction system }\end{array}$ & $\begin{array}{l}\text { Swamp forests, } \\
\text { marshes, and swamps }\end{array}$ & 3 & 3 & 6 \\
\hline DFL No 235 & $\begin{array}{l}\text { Incentive system to degraded soil recovering, proposing regulation of channels as } \\
\text { management practices. }\end{array}$ & $\begin{array}{l}\text { Regulation of channels affects the aquatic } \\
\text { system structure }\end{array}$ & Water flows (rivers) & 3 & 2 & 5 \\
\hline DFL N 701 & Afforestation development to soil recovery, making economic exploitation available. & $\begin{array}{l}\text { Forest development results in swamp forest } \\
\text { destruction (replacement by exotic species) }\end{array}$ & Swamp forests & 3 & 2 & 5 \\
\hline $\begin{array}{l}\text { Decree No } 193 \text { General } \\
\text { standards }\end{array}$ & $\begin{array}{l}\text { Assess lands suitable to forestry for quality forest development benefits, those } \\
\text { corresponding to Nadis soils. }\end{array}$ & $\begin{array}{l}\text { Development of forest Nadis soils results in } \\
\text { destruction, affecting swamp forest }\end{array}$ & Swamp forests & 3 & 1 & 4 \\
\hline \multicolumn{7}{|l|}{ DFL No 701} \\
\hline Decree $N^{\circ} 98$ Act Nº 18,450 & $\begin{array}{l}\text { Defined as drainage of structures, elements, and tasks aimed to evacuate soil waters } \\
\text { excess on surface or subsurface with restriction factor to culture development. }\end{array}$ & $\begin{array}{l}\text { Wetland draining results in complete } \\
\text { destruction of system }\end{array}$ & Swamp forests & 3 & 1 & 4 \\
\hline TOTAL RESTRICTION VALUE & & & & & & 42 \\
\hline
\end{tabular}

DFL Decree with Force of Law. 
Table 4 Restriction value and number of legal standards to different inland wetlands in Chile

\begin{tabular}{|c|c|c|c|c|c|c|c|}
\hline Legal standards & $\begin{array}{l}\text { Wetland } \\
\text { potential }\end{array}$ & Rivers & $\begin{array}{l}\text { Brackish } \\
\text { Andean } \\
\text { lakes }\end{array}$ & Lagoons & $\begin{array}{l}\text { High-altitude } \\
\text { Andean } \\
\text { peatlands }\end{array}$ & $\begin{array}{l}\text { Freshwater } \\
\text { swamp } \\
\text { forests }\end{array}$ & $\begin{array}{c}\text { Permanent } \\
\text { freshwater } \\
\text { marshes and } \\
\text { swamps }\end{array}$ \\
\hline Act $N^{\circ} 18,248$ Mining Code & 6 & 6 & 6 & 6 & 6 & 6 & 6 \\
\hline Act $N^{\circ}$ 20,256 Recreational fishing standards & 6 & 6 & 0 & 6 & 0 & 0 & 0 \\
\hline $\begin{array}{l}\text { Act } N^{\circ} 11,402 \text { Barriers and works for bank and channel } \\
\text { standardization }\end{array}$ & 6 & 6 & 0 & 6 & 0 & 0 & 0 \\
\hline $\begin{array}{l}\text { Act } N^{\circ} 18,450 \text { Standards for private investment in watering } \\
\text { and drainage systems }\end{array}$ & 6 & 0 & 0 & 0 & 0 & 6 & 6 \\
\hline DFL Nº 235 & 5 & 5 & 0 & 0 & 0 & 0 & 0 \\
\hline DFL N $N^{\circ} 701$ Forest development & 5 & 0 & 0 & 0 & 0 & 5 & 0 \\
\hline Decree № 193 General rulesDL № 701 About forest development & 4 & 0 & 0 & 0 & 0 & 4 & 0 \\
\hline $\begin{array}{l}\text { Decree } N^{\circ} 98 \text { Act } N^{\circ} 18,450 \text { Development of private investment } \\
\text { in watering and drainage systems }\end{array}$ & 4 & 0 & 0 & 0 & 0 & 4 & 0 \\
\hline Total number of standards & 8 & 5 & 1 & 3 & 1 & 5 & 2 \\
\hline Total value of legal restrictions & 42 & 28 & 6 & 18 & 6 & 25 & 12 \\
\hline
\end{tabular}

DL Decree Law, DFL Decree with Force of Law.

Table 5 Nominal and numerical real protection granted by legal rules to different types of inland wetlands in Chile

\begin{tabular}{|c|c|c|c|c|c|c|}
\hline Type of wetland & $\begin{array}{c}\text { Total protection } \\
\text { value }\end{array}$ & $\begin{array}{l}\text { Protection } \\
\text { value }\end{array}$ & $\begin{array}{l}\text { Total restriction } \\
\text { standards }\end{array}$ & $\begin{array}{l}\text { Restriction } \\
\text { value }\end{array}$ & $\begin{array}{l}\text { Real protection } \\
\text { value }\end{array}$ & $\begin{array}{c}\text { Numeric } \\
\text { protection value }\end{array}$ \\
\hline Wetlands & 47 & 144 & 8 & 42 & 102 & 3 \\
\hline Rivers & 46 & 141 & 5 & 28 & 113 & 3 \\
\hline Brackish Andean lakes & 27 & 80 & 1 & 6 & 74 & 1 \\
\hline Lagoons & 44 & 134 & 3 & 18 & 116 & 3 \\
\hline High-altitude Andean peatlands & 28 & 83 & 1 & 6 & 77 & 1 \\
\hline Swamp forests & 32 & 98 & 5 & 25 & 73 & 1 \\
\hline Permanent freshwater marshes and swamps & 34 & 102 & 2 & 12 & 90 & 2 \\
\hline
\end{tabular}

and involve payments for environmental services and penalties for damage to the ecosystem. They consider compensatory wetland restoration. Analysis of measures reveals that these have to do with the creation of new incentives rather than eliminating those perverse incentives which favor, fill, and convert wetlands to agricultural soils or urban with bonus or by other means (see national reports of countries mentioned ${ }^{\mathrm{i}}$ ).

Table 6 Nominal and numerical protection value granted by law to different types of wetlands

\begin{tabular}{lccc}
\hline Nominal value & Rate & $\begin{array}{c}\text { Real protection } \\
\text { number value }\end{array}$ & Type of wetland \\
\hline Low protection & $\leq 87$ & 1 & $\begin{array}{c}\text { Brackish Andean lakes } \\
\text { High-altitude Andean } \\
\text { peatlands }\end{array}$ \\
& & 2 & $\begin{array}{c}\text { Swamp forests } \\
\text { Intermediate } \\
\text { protection }\end{array}$ \\
$\begin{array}{l}\text { High protection } \\
\text { Hignanent freshwater }\end{array}$ & $\geq 103$ & 3 & $\begin{array}{c}\text { Permarshes and swamps } \\
\text { Rivers and lagoons }\end{array}$ \\
\hline
\end{tabular}

Based on the formerly mentioned, three actions must be implemented in Chile to improve conservation and rational use of wetlands: 1) Repeal rules which promote destruction of wetlands through incentives. 2) Discuss a special law for proper management and conservation of wetlands, including tax incentives and the corresponding regulation to operate. 3) Prioritize conservation actions for wetland types with low protection value such as swamp forests, peatlands, and brackish Andean lakes.

\section{Conclusions}

In Chile practically, there are no specific legal regulations on wetlands; there are only some decrees which applied indirectly to these ecosystems, addressed only to some components (water quality and quantity and wild species), without ecosystem approach. Current legal regulations in Chile do not allow a proper protection of wetlands and rational use as mandated by the committed country as a member of the Ramsar Convention. In Chile, to improve wetland conservation conditions, every incentive promoting 
wetland destruction must be eliminated; promulgate specific regulations for proper management and conservation of wetlands including tax incentives and corresponding operating regulations; and favor conservation actions to less protected wetland, such as swamp forests, peatlands, and brackish Andean lakes.

\section{Endnotes}

${ }^{a}$ http://www.ramsar.org/library/field_documents\% 253Afield_language/english-1/field_tag_body_event/ cop11-bucharest-2012-415

bhttp://www.ramsar.org/sites/default/files/documents/ pdf/cop11/nr/cop11-nr-usa.pdf

${ }^{c}$ http://www.ramsar.org/sites/default/files/documents/ pdf/cop11/nr/cop11-nr-canada-e.pdf

${ }^{d}$ http://www.ramsar.org/sites/default/files/documents/ pdf/cop11/nr/cop11-nr-uk.pdf

ehttp://www.ramsar.org/sites/default/files/documents/pdf/ cop11/nr/cop11-nr-china.pdf

fhttp://www.ramsar.org/sites/default/files/documents/pdf/ cop11/nr/cop11-nr-australia.pdf

ghttp://www.ramsar.org/sites/default/files/documents/ pdf/cop11/nr/cop11-nr-newzealand.pdf

h http://www.ramsar.org/library/field_documents\% 253Afield_language/espa\%C3\%B1ol-4/field_tag_body_ event/cop11-bucharest-2012-415/field_tag_countries/ neotropics-15?search_api_views_fulltext $=$ \&items_per_page $=20$

\section{Additional file}

Additional file 1: Complementary background.

\section{Competing interests}

The authors declare that they have no competing interests.

\section{Authors' contributions}

PM developed the methodology, conducted legal review and drafted the manuscript. AM participated in the design of the methodology, in writing and revision of the manuscript. Both authors read and approved the final manuscript.

\section{Acknowledgements \\ We thank to projects: management and restoration measures of wetland ecosystems in southern Chile, Ministry of Environment (2011-2012); identification of potential areas to establish reserves aimed to the protection of native fauna of freshwater aquatic species, FIP No. 2008-58, Fisheries Research Fund (2009-2010); analysis of biodiversity in Antofagasta Region (2007-2008) CONAMA, FNDR, all of them executed by Center for Agricultural and Environmental Studies. Also, we thank Charif Tala (Ministry of Environment) for his comments and suggestions to methodology. AMP appreciates the contribution of the General Direction for Research and Graduate Studies at the Catholic University of Temuco, DGIPUCT project No. CD2010-01 and Project 0804 MECESUP UCT.}

\section{Author details}

${ }^{1}$ Facultad de Ciencias, Universidad Austral de Chile, Casilla 567, Valdivia, Chile. ${ }^{2}$ Programa de Humedales, Centro de Estudios Agrarios y Ambientales, Casilla 164, Valdivia, Chile. ${ }^{3}$ Núcleo de Estudios Ambientales NEA, Escuela de Ciencias Ambientales, Facultad de Recursos Naturales, Universidad Católica de Temuco, Casilla 15-D, Temuco, Chile.
Received: 12 May 2014 Accepted: 22 October 2014

Published online: 08 November 2014

\section{References}

Abell R (2002) Conservation biology for the biodiversity crisis: a freshwater follow-up. Conserv Biol 16:1435-1437

Abell R, Allan JD, Lehner B (2007) Unlocking the potential of protected areas for freshwaters. Biol Conserv 134:48-63

Asenjo R (2006) Institucionalidad pública y gestión ambiental en Chile. Expansiva, serie. In: Foco., p 91

Bahamonde N, Carvacho A, Jara C, López M, Ponce F, Ma Retamal E, Rudolph E (1998) Categorías de conservación de decápodos nativos de aguas continentales de Chile. Bol Mus Nac Hist Nat 47:91-100

Barbier E, Acreman M, Knowler D (1997) Valoración económica de los humedales. Guía para decidores y planificadores. Oficina de la Convención de Ramsar, Gland, Suiza

Brañes R (2000) Manual de Derecho Ambiental. Fundación Mexicana para la educación Ambiental, Editado por Fondo de Cultura Económica, $2^{\circ}$ edición. Ciudad de México

Bravo D (2010) Conservación y preservación de los humedales en Chile. Justicia ambiental: Revista de Derecho Ambiental de Fiscalía del Medio Ambiente/ FIMA 2:91-158

Castillo M (1994) Régimen jurídico de protección del medio ambiente. Aspectos generales y penales. Segunda edición. Ediciones Bloc, Santiago de Chile

CEA/FIP (2010) Estudio identificación de áreas potenciales para establecer reservas destinadas a proteger la fauna nativa de especies hidrobiológicas de agua dulce Centro de Estudios Agrarios y Ambientales/ Fondo de Investigación Pesquera, Informe Final

CONAF-CONAMA (1997) Catastro y evaluación de los recursos vegetacionales nativos de Chile. Editado por CONAF/CONAMA, Chile

CONAMA (1996a) Aire, flora, fauna, áreas silvestres protegidas, procedimientos administrativos ambientales, Documento 13, Serie Jurídica

CONAMA (1996b) Diversidad biológica, identificación y diagnóstico preliminar del ordenamiento jurídico aplicable a la protección de la diversidad biológica, Documento 16, Serie Jurídica

CONAMA (1997a) Áreas silvestres protegidas, legislación punitiva y sancionatoria ambiental, Documento 27, Serie Jurídica

CONAMA (1997b) Áreas silvestres protegidas, legislación sancionatoria ambiental, Documento 28, Serie Jurídica

CONAMA (2009) Ley sobre bases generales del medio ambiente y sus reglamentos. Editado por Comisión Nacional del Medio Ambiente, Santiago, Chile

Coperland C (2010) Wetlands: an overview of issues. Congressional Research Service Reports. Paper 37

Dahl Te (2000) Status and trends of wetlands in the conterminous United States 1986 to 1997. U.S. Department of the Interior, Fish and Wildlife Service, Washington, D.C

Díaz-Paéz E, Ortiz J (2003) Evaluación del Estado de conservación de los anfibios en Chile. Rev Chil Hist Nat 76:509-525

Dudley N (ed) (2008) Directrices para la aplicación de las categorías de gestión de áreas protegidas. UICN Gland, Suiza

Dugan P (1992) Conservación de Humedales. Un análisis de temas de actualidad y acciones necesarias. UICN, Suiza

Echeverría H (2008) Proyecto Capacitación en base de una Revisión de la Legislación e Institucionalidad relacionada con la Gestión de Humedales en el Ecuador (WFF/06/EC/2), Centro Ecuatoriano de Derecho Ambiental/ Ministerio del Ambiente del Ecuador

Fernández P (2004) Manual de Derecho Ambiental Chileno. Editorial Jurídica de Chile

Figueroa R, Palma A, Ruiz V, Niell X (2007) Análisis comparativo de índices bióticos utilizados en la evaluación de la calidad de las aguas en un río mediterráneo de Chile: río Chillán, VIII Región. Rev Chil Hist Nat 80(2):225-242

Gallardo E (1985) Legislación sobre protección de la flora arbórea y arbustiva nativa chilena. In: Benoit IL (ed) Libro rojo de la flora terrestre de Chile (Primera Parte). Corporación Nacional Forestal, Santiago de Chile

García A (2005) Análisis estructural y estado de conservación de los rodales costeros de temu y pitra, entre Imperial y Queule, propuestas para su conservacion. Tesis, Universidad Católica de Temuco, Chile

Hermosilla J (2004) Tratados Internacionales vigentes en Chile en materia de protección a la Biodiversidad y su relación con la legislación interna. Facultad de Ciencias Jurídicas y Sociales. Escuela de Derecho Universidad Austral de Chile, Valdivia, Chile 
Iza AO, Rovere MB (2006) Gobernanza del agua en América del Sur: dimensión ambiental. UICN, Gland, Suiza y Cambridge, Reino Unido

Linstone H, Turoff M (1975) The Delphi Method. Techniques and Applications. Addison-Wesley, Boston, United States of America

López-Lanús B, Blanco DE (2005) El Censo Neotropical de Aves Acuáticas 2004. Global Series No. 17. Wetlands International, Buenos Aires, Argentina

Marín V, Delgado L, Vila I (2006) Sistemas Acuáticos, ecosistemas y cuencas hidrográficas. In: Vila I, Veloso A, Schlatter R, Ramírez C (eds) Macrófitas y vertebrados de los sistemas límnicos de Chile. Editorial Universitária, Santiago de Chile

Mitsch WJ, Gosselink JG (2000) Wetlands third edition. John Wiley, New York

Muñoz-Pedreros A (2004) Los humedales del río Cruces y la Convención de Ramsar. Un intento de protección fallido. Gest Amb 10:11-26

Nelson RW (1986) Wetlands policy crisis: United States and United Kingdom. Agr Ecosyst Environ 18:95-121

Novitzki R, Smith RD, Fretwell JD (1996) Wetland Functions, Values and Assessment. In: Fretwell JD, Williams JS, Redman PJ (comp). National water summary on wetland resources. United States Geological Survey. Water Supply Paper 2425. Washington, D.C.

Olivares A (2010) El nuevo marco institucional ambiental en Chile. Revi Cat Dret Amb 1(1):1-23

Ortiz S (1986) Legislación vigente en el ámbito del manejo de cuencas hidrográficas. Corporación Nacional Forestal Octava Región, Concepción, Chile

Ortiz S (1990) La actividad forestal y su regulación ambiental. Seminario CORMA sobre Legislación forestal y su dimensión en el derecho ambiental, Concepción, Chile

Peña-Cortés FA, Gutierrez PL, Rebolledo GD, Escalona MA, Bertran CE, Schlatter R, Tapia J (2006) Determinación del nivel de antropización de humedales como criterio para la planificación ecológica de la cuenca del lago Budi, Chile. Rev Geog Nor Gr 36:75-91

Peña-Cortés FA, Pincheira-Ulbrich J, Escalona-Ulloa M, Rebolledo G (2011) Cambio de uso del suelo en los geosistemas de la cuenca costera del río Boroa (Chile) entre 1994 y 2004. Rev Fac Cienc Agr Univ Nac Cuyo 43(2):1-20

Pérez-Losada M, Jara CG, Bond-Buckup G, Crandall KA (2002) Conservation phylogenetics of Chilean freshwater crabs Aegla (Anomura, Aeglidae): assigning priorities for aquatic habitat protection. Biol Conserv 105:345-353

Ramírez C, San Martín C, Rubilar H (2002) Una propuesta para la clasificación de los humedales chilenos. Rev Geog Valp 33:265-273

Ramsar (2000) Marcos para manejar humedales de importancia internacional y otros humedales. Con comprendidos de los Lineamientos adoptados por la Conferencia de las Partes Contratantes en sus reuniones 4a.,5a.,6a., y 7a. Oficina de la Convención de Ramsar, Gland, Suiza

Rodríguez-Becerra M, Espinoza G (2002) Gestión ambiental en América Latina y el Caribe: evolución, tendencias y principales prácticas. In: David W (ed) Inter Division de Medio Ambiente, Banco Interamericano de Desarrollo

Rojas M (ed) (2011) Cuadernos de Análisis Jurídico, Colección Derecho Ambiental I. Programa de Derecho y Política Ambiental. Facultad de Derecho. Universidad Diego Portales, Santiago de Chile

Schlatter RP, Espinosa LA, Vilina Y (2001) Coasts of central and southern Chile (Region 15).Chapter 3.3.3. Los Humedales de América del Sur, una agenda para la conservación de su Biodiversidad y las Políticas de Desarrollo. In: Canevari P, Davidson I, Blanco DE, Castro G, Bucher EH (eds) Resumen Ejecutivo. Wetlands International: 14 y CD. Book

Scott D, Carbonell M (eds) (1986) Inventario de Humedales de la Región Neotropical. IWRB y UICN, Reino Unido

Urrutia O (2005) Estado de conservación de los bosques pantanosos y su relación con los ecosistemas asociados en el borde costero, entre Imperial y Queule, IX Región. Tesis, Universidad Católica de Temuco, Chile

Valdovinos C (2005) Moluscos terrestres y dulceacuícolas de la cordillera de La Costa chilena. In: Smith-Ramírez C, Armesto JJ, Valdovinos C (eds) Historia, biodiversidad y ecología de los bosques costeros de Chile. Editorial Universitaria, Santiago de Chile

Valenzuela R (1994) Diagnóstico preliminar del ordenamiento jurídico vigente, en lo que se refiere a la protección de la diversidad biológica, Contrato № 01-0007-001 preparado para la Comisión Nacional del Medio Ambiente, Santiago de Chile

Veloso A (2006) Batracios de las cuencas hidrográficas de Chile: origen, diversidad y estado de conservación. In: Vila I, Veloso A, Schlatter R, Ramírez C (eds) Macrófitas y vertebrados de los sistemas límnicos de Chile. Editorial Universitaria, Santiago de Chile
Vila I, Pardo R, Dyer B, Habit E (2006) Peces límnicos, diversidad, origen y estado de conservación. In: Vila I, Veloso A, Schlatter R, Ramírez C (eds) Macrófitas y vertebrados de los sistemas límnicos de Chile. Editorial Universitaria, Santiago de Chile

Woodward RT, Wui YS (2001) The economic value of wetland services: a meta-analysis. Ecol Econ 37:257-270

Zegers G, Larraín J, Díaz F, Armesto J (2006) Impacto ecológico y social, de la explotación de pomponales y turberas de Sphagnum en la isla Grande de Chiloé. Rev Amb Des 22:28-34

doi:10.1186/s40693-014-0023-1

Cite this article as: Möller and Muñoz-Pedreros: Legal protection assessment of different inland wetlands in Chile. Revista Chilena de Historia Natural 2014 87:23.

\section{Submit your manuscript to a SpringerOpen ${ }^{\circ}$ journal and benefit from:}

- Convenient online submission

- Rigorous peer review

- Immediate publication on acceptance

- Open access: articles freely available online

- High visibility within the field

- Retaining the copyright to your article

Submit your next manuscript at $\gg$ springeropen.com 